\title{
SUBREGIONALISM WITHIN THE EU WITH SPECIAL RE- GARD TO THE GROUPINGS OF WHICH THE CZECH RE- PUBLIC IS A MEMBER
}

\author{
Eva CIHELKOVÁ, Pavel HNÁT*
}

\begin{abstract}
:
As a consequence of the third wave of regionalism, the so called new regionalism, ${ }^{1}$ a marked increase in the number of regional groupings can be observed worldwide which makes the preferential relations between states even more complicated and complex. Within these relations those in which a regional grouping is one partner are the most complex. One of such complex relationships, which did not come to being during the third wave of regionalism but was strongly supported by it, is subregionalism - simply said, overlapping of regional integrations. This development can be especially observed in the regions, where a region-wide integration scheme is being formed - such as the European Union in Europe. The aim of this study is to analyze a current state and development of subregionalism within the European Union (EU) and to analyze the effects of this phenomenon in the region. The Czech Republic, as the new member of the EU, is a member of several subregional groupings in Europe. Special regard will be taken to those groupings, where the Czech Republic is an active member. Especially the future development of these groupings will be the main expected outcome of this study. An institutional and political view (analysis of agreements and documents of regional groupings) is the primal approach of this study to the problem of subregionalism and its aim is to identify integration's state, future and relation to the dominant integration. As regionalism is the main theoretical approach of this study, it will examine only the institutionalised integration within the area and will thus omit the regional processes within the EU (the so called euroregions) or the cross-boarder cooperation between particular pairs of member states.
\end{abstract}

Keywords: regionalism, subregionalism, new regionalism, European Union, Czech Republic

JEL Classification: F01, F02, F13, F15

*) University of Economics, 4, W. Churchill Sq., CZ - 13067 Prague 3 (e-mail: cihelka@vse.cz, hnatp@vse.cz).

${ }^{\star *}$ ) This research has been supported by a grant from the Czech Grant Agency No. 402/04/0219.

1) Regionalism as a trade or economic policy of state, which leads to liberalization of relations between two or more countries and contributes to tighter links and integration between them, came into being in the first half of the $20^{\text {th }}$ century; three waves of this process can be observed. The first wave is connected with 1930 s and 1940s, the second wave with a period from 1950s to 1980s and the third wave started after the Cold War ended, e.g. in 1990s. The third wave was named the new regionalism by J. Bhagwati in 1993. Opposed to the regionalism, the new regionalism is always connected with trade agreements and its scale and scope expressively overreaches former waves of regionalism (see also Cihelková, 2004). 


\section{Subregionalism as a Theoretical Category}

\section{1 Theoretical Approaches to the Subregional Cooperation}

A rapid development of the new regionalism, which was enabled by extensive political and economical changes in the world during the 1990s, causes the growth in intensity and density of relations between the countries worldwide. As a result, an intricate web of regional groupings, that interconnect and overlay each other, comes into being. The situation, where a regional grouping is entirely (or substantially) included within another integration, is called subregionalism. The importance of this phenomenon rises significantly in recent years due to the accelerated development of world regionalism and due to new dominating actors being included into the regional cooperation. In the theory of regionalism, the subregionalism can be seen as a superstructure category, which broadens the study of main tendencies in regional integration; similarly as interregionalism and transregionalism. ${ }^{2)}$ All the three categories broaden the main stream of regional integration studies by specific features that come out form the interaction among integrations.

Several criteria can be used for the classification of subregional groupings according to their impact and relation to dominant integration. First of them are the institutional criteria - the intensity of institutional arrangement of the subregional grouping and the relation between its institutions and the institutions of the dominant integration. Another suitable criterion is the depth of regionalism, which classifies the groupings according to the depth of their own integration and according to their complementarity to the broader integration efforts. These two criteria generate two basic situations: dominant integration is deeper and more institutionalised than its subregions ${ }^{3)}$ or, on the contrary, broader (dominant) integration scheme is being constructed in an area, where deeper subregional groupings are existing or being created.

The most suitable criterion for the empirical analyses and description is the geographical criterion, which classifies the subregional groupings according to their geographical and political relation to the dominant integration into following groups:

- purely subregional integration - regional grouping which is entirely included within another dominant integration scheme

- peripheral subregional integration in the region - subregional groupings that join together several members of dominant integration with geographically or politically close countries on its outer border

- peripheral subregional processes transcending the borders of macro-region grouping which transcend the framework of geographical or political belonging with the dominant integration scheme, but still consist partly from several members of this scheme.

However, the subregionalism came into being already in the second wave of regionalism, ${ }^{4}$ ) its increased dynamics and development is interconnected particularly with the third wave of regionalism. The new regionalism (see Cihelková, 2004) chan-

2) Pure interregionalism is a situation when a preferential regional relationship is being created between two or more regional integration groupings. It is thus a similarly complex relation as the subregionalism. Transregionalism is a creation of regional integration among states (or regional groupings) from different macro-regions of the world economy. Both trends are typical for the development of the new regionalism worldwide.

3) Typical situation in Europe, where the dominant European Union is the deepest and most institutionalised regional integration in the world.

4) One example for all is the existence of Benelux within the EEC. 
ges the pattern and forms of regionalism in the whole world and its dynamics contributes to the pressure on consolidation of relationships within larger geographical areas. Integration schemes that include whole macro-regions or continents are being created on the basis of complex preferential relations' webs between most countries of the world. Subregionalism can be logically traced especially in the regions where an essential regional integration structure is being formed with a scope including substantially whole area. Typical example of this development is particularly Europe.

\section{2 European Union as a Dominant Integration}

The European Union is the most eminent regional integration created in the second wave of regionalism. The bases of toady's EU were laid down in 1952 respectively in 1957 by the establishment of three sectoral integration groupings. They evolved in their development to the deepest and most institutionalised concept of integration in the world economy. The European Union itself came into being in 1993 when the Maastricht Treaty created the three-pillar-architecture, which formally adds the cooperation in foreign and security affairs and in internal affairs and justice to the internal market. The EU is formally based on the monetary union with the elements of economic union. Crucial importance for the study of European subregionalism has, besides the form of integration, the institutionalisation of the EU. It is namely characterized by the combination of intergovernmental and supranational approaches to integration. Supranational approach can be seen especially in the existence of supranational institutions (namely the European Commission and the Court of Justice) and in the shift of national states' competences to the institutions of the integration. In its peak form this shift leads to the existence of common policies; within them the entire competence lies on the institutions of integration and the states cannot act on their own in these matters. One of the common policies is the common external policy, which is closely interconnected with the existence of regional economic integration. ${ }^{5}$

An important milestone for the analysis of subregionalism within the EU is especially a process of eastern enlargement. Nevertheless also the northern enlargement in 1995 has concrete implications. Especially in the perspective of eastern enlargement, which can be understood as a manifestation of the new regionalism in Europe, the EU includes in fact the whole European area and within it a whole range of subregional integration groupings, the existence of which in different scale influences the development of European integration process. The eastern enlargement and geopolitical changes that enabled it invoke the formation of regional integration in Central and Eastern Europe during the accession process and as the enlargement moves on many of these groupings become subregional. Especially recently, the subregionalism in the EU develops dynamically and even the approach of the EU itself to its subregional integrations changes substantially.

5) Member States of the EU cannot solely act in the matters of tariff or non-tariff barriers to trade and it is thus impossible for them to build a shallow form of regional integration (free trade area or custom union). Simultaneously, the state that is to become a Member State of the EU has to leave such groupings. 


\section{Subregionalism in the EU}

\section{1 Purely Subregional Groupings}

There are three purely subregional organisations within today's EU. The first and oldest of them is the Benelux Economic Union (further Benelux), an integration project created even before the EEC came into being. The latter two are interconnected with geopolitical changes in Europe after 1989 and consequently with the eastern enlargement process. These are the Visegrad Group and Baltic Council. As the Czech Republic is a member of the Visegrad Group, the main focus will be placed to this grouping, using other two examples as a comparative criterion.

Benelux is an integration grouping created on the basis of long-term convergence and common history of three strategically situated states in Europe - of the $\mathrm{Ne}$ therlands, Belgium and Luxembourg. It became a concrete form, as a result of many initiatives after 1944, by the agreement on establishment of a custom union that came into force on $1^{\text {st }}$ January 1948 . Current agreement constituting the relations between countries of Benelux was signed in 1958 and on its bases an economic union was created. Additionally, as a part of this process, bilateral relationship between Belgium and Luxembourg constituted into the form of monetary union. Main goals of Benelux economic union are the support of free movement of goods, persons, services and capital, to which projects in regional cooperation on numerous aspects (such as environment, defence, migration politics, intellectual property rights) are added.

Benelux countries are founding members of all three sectoral integrations, which laid the founction of the EU. The three countries created the European Coal and Steel Community (ECSC) in 1954 and EURATOM and European Economic Community (EEC) in 1958. Additionally, when the free trade area was established within the EEC in 1965 and the custom union in 1968, the form of Benelux integration was already deeper - monetary union between Belgium and Luxembourg and common market within the Benelux. It is thus understandable that formally deeper integration did not diminish within the EEC but, on the contrary, prospered further and created an example and pattern for the creation of the Internal Market within the EU in 1993 and the European Monetary Union (EMU) in 1999; all Benelux countries are members of these projects of European integration. The Benelux countries managed to use the advance of their integration project compared to the EC/EU to create an example for leading European integration, inspiring in many matters, and to gain positive effects of their mutually proven cooperation and to find always another reason for its existence within the EU. Even today, when the form of integration is substantially the same, Benelux has the reason for its existence namely in the long-term and proven cooperation and mutual coordination in the fields of common interest, which manifest itself within the complicated framework of the decision-making mechanism of the EU. Namely due to the shift of EU goals to the project of political and security cooperation, the Benelux regains a mild advance and is again seen as an example of effective cooperation on this field.

The Visegrad Group (V4) is the result of four Central European states' - the Czech Republic, Hungary, Poland and Slovakia - efforts towards cooperation. It was logically based namely on transformation efforts of the economies on their way into the EU. Since its establishment in 1991, this grouping has been strongly influenced by the existence of the EU, which within the framework of its stabilization efforts in Central and Eastern Europe (consequently resulted in eastern enlargement), strongly pursued the creation of both formal and informal regional groupings in the region. However, the Visegrad Group remained during its existence behind the EU borders a regional forum for political, security and cultural relations between its members; the 
Central European Free Trade Agreement (CEFTA) ${ }^{6}$ created on the basis of the V4 in 1993 pulled economical impetus away. However, there were many matters of common interest to be solved within the V4 before the EU enlargement, its activity stagnated after the initial success with creation of CEFTA, mainly due to the conflicts and different approaches to integration among its members, and restricted itself on mutual consultations, projects and declarations. Its main activity focused on fostering of cultural cooperation, education and on efforts on closer relations with Western European institutions. However, a revival to the V4 activity was brought by the final preparations of NATO and EU enlargement. The institutional structure of the V4 is relatively small and is based purely on intergovernmental approach with rotating presidency; it consists of ministerial meetings and consultations and annual summit of Member States' presidents. Common projects are co-financed by the Visegrad Fund.

Efforts of Member States to rejoin the European community and their membership in European integration process was the crucial motive for the existence of their regional cooperation and the fulfilment of this goal in 2004 means substantial changes in the existence of the V4. Due to the character of mutual cooperation, which was always seen as a complement to the European integration process, the V4 survived its members' accession to the EU, however, it is still looking for a precise place in European decision-making process. Its reaction on eastern enlargement was formulated by the Declaration in Kroměříz on 12th May 2004, which named the main fields of the future cooperation within the EU. Within the framework of mutual cooperation these fields are namely in cultural cooperation, education, civic society, border cooperation, environment but also defence, security and internal affaires and consultations in foreign policy. Besides these fields, of which all are being addressed on the EU level too, the V4 found issues for cooperation with the institutions of the EU, namely in foreign and security policy, Schengen system, new form of economic cooperation and consultations on preparations for the membership in the EMU. The last part of declaration concerns the cooperation with other institutions, namely with NATO on the support of other states candidacy concerning membership and stresses the cooperation between the EU and NATO with special significance of transatlantic relations.

The Baltic Council is an intergovernmental cooperation among three Baltic republics - Estonia, Latvia and Lithuania - other post-communistic countries, which became the EU Members in 2004. Similar ideas about the influence of the European integration process on the formation of regional cooperation in Central and Eastern Europe are thus valid for the creation of existence of this integration. The Baltic Council is, however, also specifically influenced by the institutional arrangement of the Nordic Council; ${ }^{7}$ this is understandable especially for the geographical and cultural proximity of both regions. The Baltic Council came into being on the basis of common parliamentary assembly of the three states in 1993, which called for the creation of institutional framework for promising intergovernmental cooperation. The activity of the Baltic Council focused mainly on creation of free trade area, visa policy, transportation, education and military cooperation. Even though some of the ambitious projects such as custom or military union were not successful due to external factors, ${ }^{8)}$ the Baltic cooperation prospered and got another concrete result

6) CEFTA will be studied closer in this text, but according to consequent waves of its enlargement (some countries remained out of the EU) it is not purely subregional and will be examined in the next chapter.

7) The Nordic Council is a grouping of both Members and non-Members of the EU and will therefore be explored in the next chapter.

8) Similarly as the Visegrad Group, also in the case of the Baltic Council, the integration into the EU was preferred to the more formal cooperation between the candidate states; the military cooperation was influenced mainly by the integration into the NATO. 
through the creation of the Baltic Free Trade Agreement (BAFTA). BAFTA came into being on $1^{\text {st }}$ April 1994 and has been enlarged to the agricultural trade too since 1997. Factual effects of BAFTA remained, due to similar export orientation of member states, rather small and BAFTA did not lead to major growth of intra-trade. Since the BAFTA did not step over the formal integration framework of the EU, it disappeared after its member's accession to the EU altogether and is thus an example of integration efforts that were replaced by the common rules of the EU.

Other field of cooperation in the Baltic Council reached formally higher level and thus continue even after the member states' accession to the EU. However, similarly as the Visegrad Group, they need reconsidering. The $10^{\text {th }}$ meeting of the Baltic Council responded to the eastern enlargement by an institutional reform, which decreased the number of areas of mutual cooperation to five: defence, energy, internal affaires, transportation and telecommunications and environment. In the terms of cooperation with the EU, the Baltic Council should become a forum of mutual cooperation and coordination of Baltic states, namely in the matters of regional policy, agriculture, transportation and other priorities of the new cooperation. Within the framework of security policy, the relationship to NATO, which the Baltic States also entered, remains crucial.

While the Benelux integration arose from the naturally favourable background for integration and was established before its members entered the EEC, the integration processes in Central and Eastern Europe (within them the Visegrad Group and Baltic Council) are from a great part a reaction to the already existing integration process in Western Europe. The Visegrad Group and Baltic Council were established, as mentioned above, also due to the pressure of the EU on the formation of regional cooperation in Central and Eastern Europe and their existence is thus induced by the influence of the European integration process. However, during their existence both groupings aimed to access the EU and their cooperation was, due to mutual conflicts and individual approach to candidate countries, always separated from the integration into the EU. Both cooperations thus developed into the form, which is firstly purely complementary to the EU process and secondly reaches higher levels of integration, which does not belong to the exclusive competence of the EU institutions. As a result of this fact, the Visegrad Group and Baltic Council are compatible with the membership in the EU and keep on existing. Their today's role is strongly connected with the continuing process of integration of their members into western European institutions (namely into EMU and due to the shift of goals also to the cooperation in foreign and security policy). Additionally they can, similarly as Benelux, become a forum for mutual coordination, which can strengthen a position of its Member States within the decision-making mechanism of the EU. The question whether this vision is possible remains, because there were some problems in mutual cooperation even before the EU accession. The latest declarations and development, however, indicate that the member states of the Visegrad Group and Baltic Council realize the opportunities of their subregional groupings for the enforcement of their position within the EU.

\section{2 Peripheral Subregional Integration in European Region}

Besides the subregional integration of EU Member States, there is a range of integration schemes on the border of today's EU, whose members are several Members and non-Members of the EU. However, these groupings are thus not purely subregional, their impact on the activity and future of the EU can be even higher than is that of purely subregional groupings. Subregional integration on the periphery often coheres with the process of enlargement and thus prepares way for the enlar- 
gement process in some aspects. Additionally, after the enlargement, many of these groupings can become purely peripheral. Contemporarily, following subregional integrations can be found on the EU periphery: Nordic Council, Council of Baltic Sea States, Central European Initiative and a specific example, which is the Central European Free Trade Agreement. The latter two are those of which the Czech Republic is a member.

The Nordic Council is today a grouping formed by Denmark, Norway, Sweden, Finland, Iceland and three independent territories (Greenland, the Faroe Islands and Äland), which has developed from initial efforts since 1944 in the field of legislature into an intergovernmental cooperation in a whole range of matters in the area of Scandinavia. Similarly as the Benelux, the Nordic Council gained positive effects from historical interdependence of the region. Based on the principle of intergovernmental approach and decisions by consensus, the Nordic Council enhance the integration of its members in the whole range of areas, which mainly belong to the creation of common and internal market. For example, in 1954, the Nordic Council created a passport union enabling the free movement of persons within its borders, the arrangements of which were not overcome until the existence of Schengen System (Norway and Iceland are its members from non-Member states of the EU). Based on the range of agreements, there is a common regulation of labour market, social security, education, environment, energy, transportation or agriculture within the Nordic Council - all these activities are today addressed on the EU level too and thus the Nordic Council contributes to the homogeneity of the European Economic Area (EEA). ${ }^{9)}$ The Nordic Council itself has as its priorities the support of implementation of the EU legislature to foster the mobility in Nordic countries.

The Nordic Council gained subregional character due to two waves of outflow of its members into the EC/EU. Concerning the relation between the EU and Nordic Council, the Nordic Council is, however, it came into being sooner and independently on the European integration process, a policy-taker. However, through the membership of Denmark, Finland and Sweden, the Nordic Council has some direct influence on the EU policy making and it arranges its relation to EU institutions by agreements. In a whole range of matters, the Nordic Council has due to an effective cooperation still an advance compared to integration in the EU.

The Council of Baltic Sea States (CBSS) has today 12 members: Denmark, Estonia, Finland, Germany, Iceland, Latvia, Lithuania, Norway, Poland, the Russian Federation, Sweden and the European Commission. It was established in 1992 at the ministerial meeting of 10 states and the Commission in Copenhagen; Iceland accessed in 1995. The CBSS is a regional forum for intergovernmental cooperation, which focuses on intensive cooperation in all issues of common interest excluding military cooperation. The Baltic Sea states address together economical cooperation, agriculture, energy, education, regional policy, justice and internal affaires, transportation or industrial policy. Since 1996, the prime ministers meet biannually and since 1998 the activity of the CBSS has been supported by permanent Secretariat in Stockholm. France, Italy, the Netherlands, Slovakia, Ukraine, Great Britain and the United States have the observer status and take part in the CBSS meeting regularly.

9) The European Economic Area has constituted a factual enlargement of the EU Internal Market by the countries of the European Free Trade Area (EFTA) since 1994 - Norway and Iceland are members of both EFTA and Nordic Council. Due to the EEA, the countries outside the EU have to implement the EU legislature. Additionally, EFTA's reaction the existence of the EEA was the Vaduz Convention, which constituted common market within to EFTA in 2002. 
After the eastern enlargement, 8 of the CBSS members are also the members of the EU, which stresses the significance of this cooperation for the EU, which is formally expressed also by the membership of the European Commission in this subregional cooperation. Scope of the CBSS activity, similarly to all examined subregional integrations, is closely interconnected with present priorities of the dominant European integration and thus supports the efforts taken within the EU. Additionally the CBSS has a basic importance for the external relations of the EU, especially for the current efforts of the EU to cooperate closely with its neighbours (Northern Dimension Action Plan, New Neighbourhood Policy, etc.). Crucial role of CBSS is, concerning external relations of the EU, given namely by the membership of the Russian Federation, a crucial partner of the EU. Main priorities that the EU influences through the CBSS are environment, nuclear safety, energy, the Kaliningrad matter, transport infrastructure, commercial cooperation or justice and internal affaires. The CBSS thus becomes an important mediator for the institutional structure of the EU in the matter of external relations, as it enables a day-to-day cooperation between the EU and its members in the Baltic region, including Russia. In the field of external relations, the most important role of the peripheral subregional cooperations can be seen, as the analyses have suggested so far.

The Central European Initiative (CEI) is the most numerous subregional process at the periphery of the EU, as it has 17 members today: Albania, Austria, Belarus, Bosnia and Herzegovina, Bulgaria, Croatia, the Czech Republic, Hungary, Italy, Macedonia, Moldova, Poland, Romania, Serbia and Monte Negro, Slovakia, Slovenia and Ukraine. After the eastern enlargement, 7 of 17 members are simultaneously members of the EU; Bulgaria, Romania and Croatia are the candidate states today. The CEI was established in 1989 as an intergovernmental forum for economical, political and cultural cooperation with the main goal to assist the transitive economies converging the EU. After the southeast enlargement of the CEI in late 1990s, its scope has changed, however, its main goal, to support Central and Eastern European states' preparations to potential full membership in the EU, remained. The beginning of the $\mathrm{CEI}$ is in the days after the dramatic events in Berlin in November 1989, when the representatives of Italy, Austria, Hungary and Yugoslavia signed the agreement on mutual cooperation - the so called Quadrilateral Cooperation. ${ }^{10)}$ By the accession of Czechoslovakia in May 1990, the cooperation broadened to the Pentagonal Initiative and in 1991 by accession of Poland to the Hexagonal Initiative. During next wave of enlargement in 1992, by successor states of former Yugoslavia, the Initiative was officially named as the Central European Initiative. In 1995 the CEI was joined by its candidate states - Belarus, Bulgaria, Ukraine, Romania and Albania. Moldova became the $16^{\text {th }}$ member ${ }^{11)}$ of the CEI in 1996 and last enlargement took place in 2000 with Serbia and Monte Negro becoming members.

Institutional structure of the CEI builds upon annual summit of heads of states, which takes place together with the Economical Forum, ministerial meetings, regular meetings of national coordinators and working groups in various fields of common interest, mainly connected with the transformation (economics, human rights,

10) When this agreement was signed, only Italy was a Member of the EU and thus the Initiative was often seen as an effort of Italy to gain a moderate role within the EU in the process of Central and Eastern Europe's stabilization. Austria, whose interest in the regional stabilization is eminent, accessed the EU (from the great part as a reaction to geopolitical changes in the region) in 1995. Hungary, as an original member, accessed the EU in 2004. And after the split of Yugoslavia, all its successor states became gradually members of the CEI; Croatia as the first of them became EU's official candidate for membership.

11) The accession of the Czech Republic and Slovakia after the split of Czechoslovakia, member state of the CEl since 1990 . 
institutional development, financial cooperation). Parliamentary cooperation and cooperation among Chambers of Commerce, fostering the commercial cooperation, are other pillars of the cooperation. Permanent Secretariat was established in Trieste in 1996 to support the activity of CEI administratively. Besides it, since 1991 the CEI has another secretariat - Secretariat for Projects established at the European Bank for Reconstruction and Development (EBRD); this illustrates a close relation of the CEI with various sources of financial cooperation during the transformation process. Moreover, the mutual projects are co-financed by the Cooperation Fund, established in 2002 from the member states' contributions.

The CEI and its relationship to the institutions of the EU is an example of the development of EU approach to the regional integration in Central and Eastern Europe. Similarly as other integrations in the region, the CEI defined its relationship to dominant integration in Europe as purely complementary not competitive. Nevertheless, the CEI was long unsuccessful in establishing permanent contacts with the European Commission, for which especially Italy ${ }^{12)}$ as a Member of the EU struggled. Although the Commission held several meetings their results were small especially due to, above mentioned, individual approach to the candidate states. By this, however, the Commission lowered the possibility of effective cooperation within the CEI and the $\mathrm{CEI}$ thus insisted on establishing the regular meetings, which it proclaimed at the summit in Trieste by an Action Plan on regular political dialogue between the $\mathrm{CEI}$ and the EU.

The position of the CEI was, similarly as the position of other subregional groupings in the area, changed by the eastern enlargement, which on one hand strengthened the position of EU Members in the CEI, and on the other eliminated some of the communication problems with the Commission caused by a strategy of the enlargement. Elimination of these barriers showed the significance of the CEI for the EU's relations with Southeastern Europe. Similarly as the Northern Dimension of external relations fosters the subregional cooperation in Northern Europe, the longterm efforts on stabilization and convergence of the Southeastern Europe is an important momentum, to which the CEI can actively contribute. Into the area of CEI, the whole range of EU's external strategies are targeted: the New Neighbourhood Policy refers to Belarus, Ukraine and Moldova (among members of the CEI); Balkan states are in center of stabilization and association process; three members of the $\mathrm{CEI}$ are already today the candidate states of the EU. The coexistence of numerous initiatives in the area can, however, lower their effectiveness.

Current Action Plan of the CEI for 2004 - 2006 thus reacts to this situation by a reform, which builds upon a concentration of activities into fewer areas than so far. For every area of CEl's activity, two priorities were set, according to their ability to be addressed by CEI more effectively than by other institutions in the region. According to the Plan, every activity of the CEI is additionally covered by cooperation with other institutions, mostly addressed are the EBRD, the EU, the Council of Europe and OECD. By this fact, the CEI itself defines its role in the European integration process' architecture and directs its priorities towards closer relations with the Southeastern neighbours of the EU. ${ }^{13)}$

12) During the Italian Presidency, the summit in Florence in 1996 even called on the European Commission for supporting the regional cooperation in the region, namely the CEI.

13) Another intergovernmental cooperation is to be found in the region today - the Black Sea Economic Cooperation. The only element of subregionalism is brought by the membership of Greece. Its members are from the CEI states (Albania, Bulgaria, Moldova, Romania, Ukraine, Serbia and Monte Negro), however, additionally its members are more geographically and culturally distant states (Armenia, Azerbaijan, Georgia). This is why this cooperation will be explored in the next chapter. 
A special example of potentially subregional integration on the periphery of the EU, potentially because similarly as BAFTA it was replaced by the common rules of the EU, is the Central European Free Trade Area (CEFTA). Agreement on CEFTA was signed in 1992 by the representatives of Czechoslovakia, Hungary and Poland (all the Visegrad Group members) and came into force in 1993, thus after the split of Czechoslovakia. In 1997 the CEFTA was enlarged by Slovenia, in 1998 by Romania, in 1999 by Bulgaria; the latest member of CEFTA has been Croatia since 2003. Its joining the CEFTA means the end of enlargement and the eastern enlargement means on the contrary disintegration for CEFTA, as all four initial members and Slovenia had to leave the CEFTA due to their accession to the EU. CEFTA continues on, however its future is more than uncertain due to a candidate status of all its three members. CEFTA lies entirely outside the EU and thus is not a subregional process, however due to the relations, which it constituted (or better said, which it prevented to disappear), CEFTA deserves its place in the analyses of subregionalism.

At the example of CEFTA, the influence of European integration on the cooperation in Central and Eastern Europe is shown. Basic momentum for the creation of CEFTA was the signing of European Agreements between the EU and its candidate states. These agreements constituted a situation where the relations between the EU and individual states of the area were better institutionalised and liberalised than the relations among the countries of the region. The main goal of CEFTA was thus to support the economic cooperation among the states of the area and not to support their membership in the EU. In the liberalization of movement of goods CEFTA went forth rapidly and the free trade area was established on $1^{\text {st }}$ January 1997 (originally planned by the end of 2000). The liberalization of agricultural goods and investment was, however, less effective, which was connected to the overall stagnation of the CEFTA process due to a prospect of full membership in the EU (a common feature of most regional integration in the area in late 1990s). On the whole, CEFTA effected the regional relations positively and contributed to the preservation of economic relations in the situation of massive reorientation of the economies toward West. CEFTA became a part of European economic integration architecture by signing a protocol enabling the accumulation of resources amoug the states of CEFTA, EU, EFTA and Baltic states.

Regarding its intuitional building, CEFTA is represented by minimal institutional structure, based only upon an annual summit of external relations' ministers. Institutional speciality of CEFTA is an incorporation of the Czech Republic-Slovakia custom union, which can be thus seen as a subregional integration within CEFTA. After the eastern enlargement, also this custom union disappeared in the internal market of the EU. ${ }^{14)}$ CEFTA will probably disappear altogether by the accession of Bulgaria and Romania into the EU. Its importance can, however, be seen in its contribution to the economic relations between candidate states before their joining the EU, which is favourable both for the candidates and the EU.

14) Minimal institutional structure of CEFTA is often connected with the perspective of the EU membership of its countries, which is due to its activity in external relations incompatible with CEFTA membership. Building strong institutions was thus seen as practically useless. 


\section{3 Peripheral subregional integration transcending the borders of Eu- ropean region}

To complete the specification of regional integration, in which the members of the EU are involved, the cooperation that transcend the geographical and cultural dimensions of Europe have to be added. Although their impact on the EU is rather small, they cannot be neglected entirely. Even from the view of subregionalism the example of transcending subregionalism is more complicated and the groupings are thus explored rather as an example of cooperation of several EU Members that is not limited to their neighbours. The special examples of subregionalism that transcend the criteria of proximity to Europe are: the already mentioned Black Sea Economic Cooperation and the Commonwealth.

The Black Sea Economic Cooperation (BSEC) has been an intergovernmental organization between Albania, Armenia, Azerbaijan, Bulgaria, Georgia, Greece, Moldova, Romania, the Russian Federation, Turkey and Ukraine since 1999; in 2004 Serbia and Monte Negro joined the BSEC. The only member of the EU is Greece, but in recent future we can count on the membership of Bulgaria and Romania, which will foster the subregional element. Main goals of the BSEC are today in the field of economy (free trade area is being planned), energy, environment and transformation reforms. A principal activity is a dialogue with the EU concerning the intensive development of cooperation with the Black Sea area (similar to the Northern Dimension of external relations). And the external relations are just the point, where the perspective of intensive cooperation with the BSEC can be found.

The Commonwealth is the community of 53 states that came into being by the transformation of the British Commonwealth of Nations into an organization for intergovernmental cooperation. Its members are today's three members of the EU: Great Britain, Malta and Cyprus and other 50 states such as Canada, Australia, India and developing countries of Africa, Caribbean and Pacific. Its scope is given by the character of member countries, mainly the developing countries, and focuses on the cooperation in development, education, democracy and human rights, economic cooperation, sustainable development and healthcare. Although the cooperation with developing countries is due to their relations to the former colonial powers in Europe addressed intensively on the European level in external and development policy, the Commonwealth can contribute to these relations further. It can be proved by the current suggestion on starting closer cooperation with the EU in a form of Strategic Partnership between the EU and the Commonwealth, which was declared at the meeting of the Commonwealth Secretary General and the President of European Commission in Brussels in March 2005. Future cooperation should focus on the field of development cooperation, multilateral liberalization within the WTO and political cooperation.

\section{Relationship between subregional Cooperations and the EU and the role of the Czech Republic}

\section{1 Relationship between Subregional Cooperation and the EU}

EU's relation to its subregional groupings is principally given by the dominant position of the European Union on the continent. Due to the deepness, scope and institutional characteristics of the leading European integration, it is fully relevant to qualify the EU as an integration, which gives the direction to the development of the whole European area and even more to all subregional integrations within its area. Even though there is a certain impact of subregional cooperation on the EU, the 
main direction of influence is just opposite: subregional integrations within the EU are principally policy takers of the institutional framework of the EU and have to adapt to it. This framework defines the space and form, which the subregional integration can take. The borders of EU's exclusive policies, within which the Member States cannot act individually, give the margins of subregional cooperation. The complexity of the EU's decision-making mechanism, however, gives enough space for implementing the subregional cooperation on different levels; upon the empirical analysis a conclusion can be made that there are many groupings that are able to utilize this space relatively effectively.

Generally we can suggest that directly within the EU, i.e. for the existence of purely subregional groupings, the space for regional cooperation in today's EU is relatively small since it is given by the ability of such groupings to offer to their member states a platform for creating a common position within the decision-making mechanism of the EU. An example of the Benelux shows that strongly interconnected economies with broad area of common interest are able to produce an effective integration even within the EU and that its impact can be apparent on the level of its decision-making. For the evaluation of such effects of the latter two subregional groupings it is too early. Their common interest has been so far namely given by their efforts to access the EU and after the fulfilment of this goal they are still looking for the stronger place in the EU's decision-making mechanism. In regard to the greater homogeneity of the Baltic region, it is more probable that it will be the Baltic Council that can follow the Benelux's example, even though also the Visegrad Group has a potential to form a stronger power among the new Members of the EU. As to the direct cooperation between the institutions of the EU and its subregional groupings, it seems that intensity of this cooperation depends mainly on the activity of subregion since the EU does not involve direct activity to support the intergovernmental cooperation among its Members and limits itself to the support of regional development.

More significant interest of the institutions of the $\mathrm{EU}$ is to be seen by the peripheral subregional cooperations, which start to represent a relatively strong tool in EU's external relations to its direct neighbours today. In some of these integrations the European Commission is even a member and participates in their day-to-day work; in others it enjoys the observer status; however, there are still cooperations that have to struggle for the Commission's interest. Commission's attitude to particular groupings is apparently given by the potential, which a certain grouping offers to support the EU's intentions. Especially the subregional groupings established in the process of eastern enlargement belong to the latter group, which is still looking for a firm place in European institutions' architecture. Generally we can suggest that the Commission grants its interest especially to homogenous groupings, such as Nordic Council or the CBSS, with a marked scale of common interests.

The main importance of these integrations hence lies in their ability to connect the Member States of the EU with countries behind its borders by projects of effective cooperation. The Northern Dimension of external relations, New Neighbourhood Policy or the stabilization and association process are the new elements of the EU's external relations, to which the peripheral subregional groupings can contribute. The scope of peripheral groupings today mostly covers the new features of EU's activity and thus allows their partial implementation in neighbouring countries. A direct impact of subregional peripheral groupings is possible only indirectly through Member States of the EU involved in subregional process; which does not mean that this impact cannot be in some cases significant. 


\section{2 The Czech Republic in the European Subregional Cooperation}

The Czech Republic is today a member of one purely subregional integration scheme - the Visegrad Group. Due to its compatibility with the membership in the EU this grouping keeps on existing. But its role within the EU is not especially strong. It is partly caused by its former development and the attitude of its Member States, including the Czech Republic. Its today's priority thus lies in finding a firm place in the architecture of European decision-making mechanism. Similarly as Benelux, the Visegrad Group could become a forum for mutual coordination, which can at least partly strengthen the position of its member states and of the Central Europe within the decision-making mechanism of the EU, although its potential and weight is not high. The possibility of this vision depends on the willingness and consensus among its particular states. The latest declarations and development however indicate that the member states of Visegrad Group realize the opportunities of their subregional groupings for the enforcement of their position within the EU and will try to utilize it.

Regarding other types of subregional cooperation, the Czech Republic is further a member of the Central European Initiative, the position of which in the European integration process is, as described above, even more complicated. The Czech Republic is active within the CEI and is focused on closer relations with the Southeastern neighbours of the EU. It could be seen as an advantage for the future as it could build firm relations with possible future Members of the EU and thus reconfirm the regional position of the Czech Republic in the EU.

The successful participation and in many cases even a leading role of the Czech Republic within the CEFTA process shows, that the Czech Republic is capable of managing its regional relations through regional agreements and thus utilize its relatively strong regional position. Nowadays, in the time of reformulating the EU's future, a stronger position within the EU is especially important.

\section{References}

Benelux websites http://www.benelux.be and http://www.bmb-bbm.org.

BSEC website http://www.bsec.gov.tr.

CBSS website. http://www.cbss.st.

CEFTA website. http://www.cefta.org.

CEl website. http://www.ceinet.org.

Cihelková, E. (2003), "External Relations of the European Union" (in Czech). Prague: C. H. Beck. (2004), "New Regionalism: Theory and Effects in the World Economy" (in Czech). In Politická ekonomie, 6/2004, pp. 807 - 822.

El-Agraa, Ali M. (1999), Regional Integration: Experience, Theory and Measurement. 2nd Edition. Houndmills, GB : Macmillan.

Fiala, P., Pitrová, M., (2003), "European Union” (in Czech). Brno : Centrum pro studium demokracie a kultury.

Hnát, P. (2004), "Regional Integration Groupings EU and NAFTA: Comparative Case Study" (in Czech). Diplomová práce. Prague: University of Economics.

Information from the Latvian Parliament. http://www3.Irs.It.

Lopadic, D. (2002), Regional Cooperation in South East Europe: the Effects of Regional Initiatives. Conference proceedings. Belgrade.

UN (2004), Meeting the Challenges in an Era of Globalisation by Strengthening Region Development Cooperation. New York: United Nations.

Nordic Council website. http://www.norden.org.

The Commonwealth website. http://www.thecommonwealth.org.

Visegrad Group website. http://www.visegradgroup.org. 